\title{
DETERMINATION OF THE DEPENDENCE OF THE NPP UNIT POWER ON THE STEAM TEMPERATURE AT THE OUTLET OF THE SUPERHEATER SEPARATOR FIRST STAGE WITH AN UNCERTAINTY OF INFORMATION
}

\author{
O.V. Yefimov, T.V. Potanina \\ National Technical University "Kharkiv Polytechnic Institute”, Kharkiv, Ukraine \\ E-mail:potaninatetiana@gmail.com;AVEfimov@kpi.kharkov.ua
}

The article discusses the application of the standard statistical approach and interval analysis procedures to the estimation of the parameters of the dependence of the power of an NPP power unit on the steam temperature at the outlet of the first stage of the superheater separator under conditions of measurements noise, unknown probabilistic characteristics of errors and with a short measurements sample. The influence of reducing the error in determining the power of the power unit on the choice of the experiment result processing method is investigated. The situation of measurement error limitation without reliable information about its distribution is considered. The correctness of the application of interval analysis numerical methods for processing experimental data under conditions of uncertainty and a significant decrease in the maximum value of the total error is shown. The data were approximated by the Levenberg-Marquardt minimization method when the relative error of the measurement results equaled $5 \%$.

\section{INTRODUCTION}

The steam separation and reheating system (SRS) of saturated steam turbines of NPP power units with a WWER-1000 reactor is very important to ensure high efficiency and reliability of their operation. Moisture separated in the separation devices $(\mathrm{S})$ in the form of a heating steam separator and heating steam condensates from the first (SS-1) and second (SS-2) stages of intermediate superheating of steam of the SSS, calculated in hundreds of tons per hour, are discharged into the corresponding housings of high-pressure heaters (HPH) of the power unit regeneration system. This has a significant impact on the material and heat balances, as well as on the reliability of operation in transient modes of the regeneration system and the entire power unit. Thus, the efficiency and reliability of the secondary circuit of NPP power units with WWER depend significantly on the efficiency of the SRS.

A significant criterion for the efficiency of the operation of the stages of intermediate superheating of steam is its temperature at the outlet from these stages at various operating modes (loads) of the power unit. The material balance in the SS-2 second stage and the steam flow through the turbine flow path, which determines its power, depends on the heated steam temperature at the outlet of the first stage of the SS-1. Therefore, the correct determination of these temperature values is very significant both in the design process of the SPR unit and during the operation of the power unit.

\section{INITIAL DATA AND TASK SETTING}

Let us consider the problem of determining the power unit electric power (load) dependence of the temperature of the heated steam at its outlet from the first stage of superheaters.

At our disposal are the data of various experiments [1] to measure the steam temperature at the outlet of the first stage when changing the electric power $N$ of the unit in the range of $50 \ldots 100 \%$ (Table). Electrical power values of the unit were obtained during the study at the fixed steam temperature at the outlet of the superheater separator first stage.

Thermal test data for the K-1000-60/1500 turbine

\begin{tabular}{|c|c|c|c|c|c|c|}
\hline$N, \%$ & 50 & 60 & 70 & 80 & 90 & 100 \\
\hline $\begin{array}{c}\text { Steam } \\
\text { temperature } \\
\text { at the outlet } \\
\text { of the first } \\
\text { stage } T,{ }^{\circ} \mathrm{C}\end{array}$ & 180.5 & 187 & 192 & 195 & 196 & 198 \\
\hline
\end{tabular}

A quantitative assessment of the effect of steam temperature on the electrical power (load) is usually performed by standard statistical methods of processing experimental results. For their application, it is necessary to fulfill significant assumptions about the properties of distortion of the data to be processed [2]:

- the sample to be measured is representative and of sufficient length;

- the total measurement error is probabilistic;

- the total error probability distribution is assumed to be a Gaussian Distribution;

- there are no chaotic components in the measurements;

- the errors of successive measurements are independent.

Unfortunately in practice, a sample of measurements is very short and the errors' probability characteristics are unknown.

Obviously that the experimental data with interval uncertainty and contain inaccuracies.

Uncertainty is a consequence of measurement and rounding errors, noise, and incomplete information.

An analysis of numerous scientific works on the processing of experimental data with uncertainty shows 
that the correct model in such a situation is the interval model [3-12].

The sample, presented in Table, contains an enough limited number of experimental points - only six measurements, and the structure and probabilistic characteristics of the measurement errors are unknown. Thus, the use of standard procedures for processing experimental data based on statistical methods is not justified.

\section{RESULTS AND THEIR DISCUSSION}

In the conditions of thermal tests of a turbine unit, the electric power values were determined with some error. For the most accurate measurement of the electric power at the terminals of the generator, the following measures are taken:

- the choice of measuring transformers with an actual error in the operating range of measurements up to $\pm(0.1 \ldots 0.2) \%$ and the adoption of measures that reduce errors to a minimum (due to the difficulty of accounting for the latter). In particular, to avoid overload, it is necessary to check the actual load of the measuring transformers, minimizing it;

- elimination of harmful effects on the accuracy of measurement;

- the connection of measuring instruments as close as possible to the output terminals and to any branch through which leakage or supply of energy from aside can occur;

- the use of two independent measurement methods simultaneously.

The value of the electrical power of the NPP power unit admits an error of 5\%. An urgent task today is to increase the capacity of the existing Ukrainian NPP power units up to $104 \%$. It is necessary to modify the systems for measuring the parameters of the first and second circuits. This modification allows you to significantly reduce the error in determining the power even up to $0.75 \%$ [13].

The data from Table contains six measurements. Suppose that the steam temperature at the outlet of the first stage of the separator-superheater has fixed exact values, and the load values allow maximum possible deviations of $5 \%$.

Taking this into account, we construct the uncertainty intervals $[2,3]$ :

$$
H_{i}=\left[\underline{h_{i}} ; \overline{h_{i}}\right]=\left[N_{i}-\Delta_{i} ; N_{i}+\Delta_{i}\right]
$$

where $\left\{N_{i}, i=\overline{1,6}\right\}=\{50,60,70,80,90,100\} \%$ ，

$\Delta_{i}-$ absolute error in $i$-observation.

So we get the intervals:

$$
\begin{aligned}
& H_{1}=[47.5 ; 52.5], H_{2}=[57.0 ; 63.0], \\
& H_{3}=[66.5 ; 73.5], H_{4}=[76.0 ; 84.0], \\
& H_{5}=[85.5 ; 94.5], H_{6}=[95.0 ; 105.0] .
\end{aligned}
$$

Fig. 1 shows the observational data and the calculated uncertainty intervals. The location of the points allows us to conclude that the function describing the change in power from the steam temperature is an exponential dependence. This fact is verified by applying the "alignment method" to the experimental data.

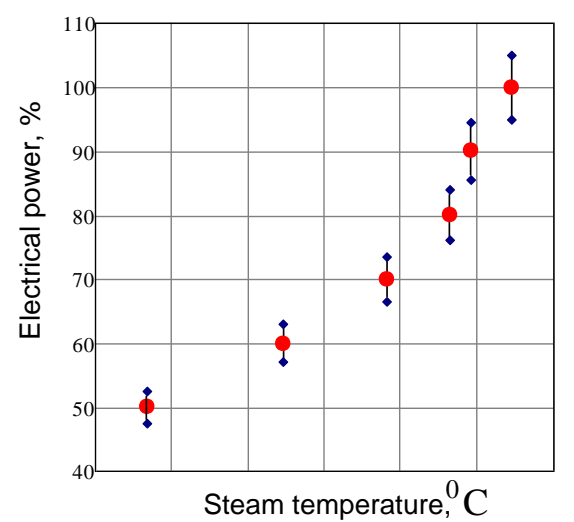

Fig. 1. Electrical power values: experimental data (bold points) and uncertainty intervals $H_{i}$ (vertical bars)

As an approximating curve, we considered a dependence of the form $f(x)=a \cdot \exp (b x)+c$. Using standard statistical approaches to experimental data processing and based on the fact that the dependence is not a linear function, the parameters of the ratio $f(x)=a \cdot \exp (b x)+c$ are determined by the method of Levenberg-Marquardt minimization [14]:

$$
N(x)=5 \cdot 10^{-10} \cdot \exp (0.128 \cdot x)+44.889,
$$

where $x$-argument ${ }^{\circ} \mathrm{C}$, steam temperature.

Curve (1) in Fig. 2 passes through all uncertainty intervals plotted for the case of $5 \%$ relative error.

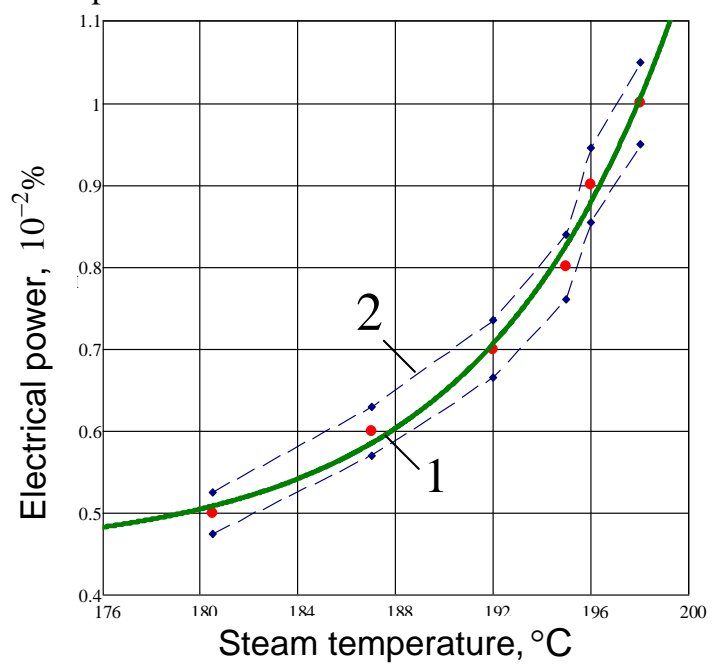

Fig. 2. Dependence of the NPP unit power on the steam temperature: 1 - curve fit (3); 2 - tube of uncertainty intervals $H_{i}(2)$

In a situation where the error in the observed power values decreases to $1 \%$, the approximation curve (Fig. 3) does not pass through all the measurement uncertainty intervals:

$$
\begin{aligned}
H_{1}^{*} & =[49.5 ; 50.5], H_{2}{ }^{*}=[59.4 ; 60.6], \\
H_{3}{ }^{*} & =[69.3 ; 70.7], H_{4}{ }^{*}=[79.2 ; 80.8], \\
H_{5}{ }^{*} & =[89.1 ; 90.9], H_{6}{ }^{*}=[99.0 ; 101.0] .
\end{aligned}
$$


The estimation of the root-mean-square scatter $\sigma$ of the measurements relative to the approximating curve was $\sigma=17.8 \%$.

From the curve (1) parameters, it can be seen that the decisive role in the expression is played by the parameter $c=44.889$.

It is necessary to estimate the permissible range of compatible values of parameters $\tilde{a}, \tilde{b}, \tilde{c}$ in expression: $N(x)=\tilde{a} \cdot \exp (\tilde{b} x)+\tilde{c} . \quad$ In $\quad[15], \quad$ an algorithm for calculating the range of permissible values using interval analysis methods is considered.

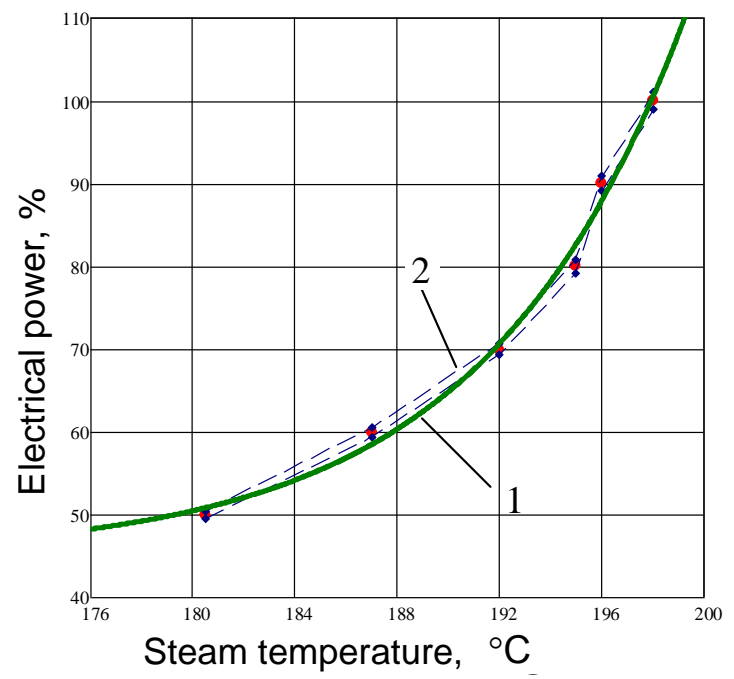

Fig. 3. Dependence of the NPP unit power on the steam temperature: 1 - curve fit (3); 2 - tube of uncertainty

intervals $H_{i}{ }^{*}$, with a measurement error of $1 \%$

The main principles of the proposed approach:

- the transition to the natural logarithm scale is carried out, a new auxiliary interval variable $z$ and the uncertainty intervals of its measurements are obtained

$$
\begin{gathered}
z=\ln (N(x)-\tilde{c})=\tilde{b} x+\ln \tilde{a}, \\
\mathbf{z}=[\underline{z}, \bar{z}], \underline{z}=\ln (N-E), \bar{z}=\ln (N+E),
\end{gathered}
$$

where $E$ - total error limit;

- dependence (5) is linear in argument $x$ and, together with uncertainty intervals (6), forms a system of linear interval inequalities

$$
\tilde{\mathbf{b}} x+\ln \tilde{\mathbf{a}} \subseteq \mathbf{z} .
$$

The determining interval coefficients in a linear relationship problem was successfully solved by the article authors in $[5,6,9,10]$.

\section{CONCLUSIONS}

Currently, the capacity increasing problem of the operated Ukrainian NPP power units due to the rational use of the existing resource, improving the systems for measuring the parameters of the equipment of the first and second circuits, is being actualized. The plan is to increase the capacity to $104 \ldots 106 \%$. Measuring systems modification reduces the error in determining the power of a power unit up to $1 \%$, even up to $0.75 \%$.

With such measurement accuracy, standard statistical methods for processing experimental results and nonlinear approximation procedures give a result that is inconsistent with the sample of observations.

The use of interval analysis methods provides an alternative flexible tool for obtaining more accurate and complete analysis of experimental data in the presence of incomplete information.

\section{REFERENCES}

1. V.A. Buzlukov, M.G. Teplitskiy, L.B. Oyberman, A.V. Yefimov, A.A. Palagin, Ye.D. Men'shikova. Obtaining the characteristics of the turbine units equipment by the full-scale computing experiment method // Teploenergetika. 1987, N 8, p. 19-21 (in Russian).

2. S.I. Kumkov, Yu.V. Mikushina. Interval Approach to Identification of Catalytic Process Parameters // Realible Computing. 2013, N 19(2), p. 197-214.

3. R.E. Moore, R.B. Kearfott, M.J. Cloud. Introduction to interval analysis. Society for Industrial and Applied Mathematics, Philadelphia, 2009, 223 p.

4. S.P. Shary. The finite-dimensional interval analysis. Novosibirsk: "XYZ Publ.", 2016, 606 p.

5. A.V. Yefimov, M.M. Pylypenko, T.V. Potanina, et al. Processing of experimental data of the process of refining nuclear material $\mathrm{Zr} 1 \% \mathrm{Nb}$ by electron-beam melting by means of interval analysis methods // Problems of Atomic Science and Technology. Series "Physics of Radiation Effect and Radiation Materials Science”. 2019, N 5, p. 118-123.

6. O. Yefimov, M. Pylypenko, T. Potanina, et al. Materials and decision support systems in the nuclear power industry. LAP LAMBERT Academic Publishing, 2020, $135 \mathrm{p}$.

7. T.V. Potanina, O.V. Yefimov. Application of interval analysis for improving the reliability of the assessment of hardness values spread of nuclear structural materials // Problems of Atomic Science and Technology. Series "Physics of Radiation Effect and Radiation Materials Science”. 2020, N 1, p. 206-210.

8. T.V. Potanina, O.V. Yefimov. Application of interval analysis method for determining operating characteristics of NPP power units // Bulletin of the National Technical University "KhPI". Series "Hydraulic machines and hydraulic units". 2019, N 2, p. 77-81.

9. T.V. Potanina, O.V. Yefimov, G.L. Khavin. Modeling NPP power unit steam turbine installation steam separator-superheater temperature characteristics by interval methods // Bulletin of the National Technical University "KhPI". Series "Mathematical modeling in engineering and technologies". 2020, N 1, p. 87-95.

10. T.V. Potanina, A.V. Yefimov, T.A. Harkusha, T.A. Yesipenko. Application of interval analysis methods for NPP power units safety and reliability assessment // Yaderna ta radiatciyna bezpeka. 2018, N 3(79), p. 23-29 (in Ukrainian).

11. T.V. Potanina, O.V. Yefimov, M.M. Pylypenko. Estimation of the dependence parameters of nuclear structural materials hardness on the content of gas impurities: an interval approach // Problems of Atomic Science and Technology. Series "Physics of Radiation 
Effect and Radiation Materials Science”. 2021, N 5, p. 77-83.

12. S.P. Shary. Data fitting problem under interval uncertainty in data // Industrial laboratory. Materials diagnostics. 2020, v. 86, N 1, p. 62-74.

13. CTS.1.0023.3468. Conceptual technical solution to increase the heat capacity of the reactors of the operating power units No. 1, 2 of the SUNPP OP to 3,045 MW. Kyiv, 2015, No. CTS.1.0023.3468, 7 p.
14. K. Madsen, N.B. Nielsen, O. Tingleff. Methods for nonlinear least squares problems: Technical Report. Informatics and Mathematical Modeling, Technical University of Denmark, 2004, 58 p.

15. S.I. Kumkov. Processing experimental data on ionic conductivity of molten electrolyte using interval analysis method // Melts. 2010, N 3, p. 79-89.

\title{
ОПРЕДЕЛЕНИЕ ЗАВИСИМОСТИ МОЩНОСТИ ЭНЕРГОБЛОКА АЭС ОТ ТЕМПЕРАТУРЫ ПАРА НА ВЫХОДЕ ИЗ ПЕРВОЙ СТУПЕНИ СЕПАРАТОРА- ПАРОПЕРЕГРЕВАТЕЛЯ В УСЛОВИЯХ НЕОПРЕДЕЛЕННОСТИ ИНФОРМАЦИИ
}

\author{
А.В. Ефимов, Т.В. Потанина
}

Рассматривается применение стандартного статистического подхода и аппарата интервального анализа к оцениванию параметров зависимости мощности энергоблока АЭС от температуры пара на выходе из первой ступени сепаратора-пароперегревателя в условиях неопределенности информации: наличия «шума» в измерениях, неизвестных вероятностных характеристиках погрешностей и при достаточно короткой выборке наблюдений. Исследуется влияние уменьшения погрешности определения мощности энергоблока на выбор метода обработки результатов эксперимента. Рассматривается ситуация ограниченности погрешности измерений без достоверной информации о ее распределении. Показана корректность применения численных методов интервального анализа для обработки экспериментальных данных в условиях неопределенности и существенного уменьшения максимального значения суммарной ошибки. При стандартной 5\% относительной погрешности результатов измерений выполнена аппроксимация данных методом минимизации Левенберга-Марквардта.

\section{ВИЗНАЧЕННЯ ЗАЛЕЖНОСТІ ПОТУЖНОСТІ ЕНЕРГОБЛОКА АЕС ВІД ТЕМПЕРАТУРИ ПАРИ НА ВИХОДІ $З$ ПЕРШОГО СТУПЕНЯ СЕПАРАТОРА- ПАРОПЕРЕГРІВНИКА В УМОВАХ НЕВИЗНАЧЕНОСТІ ІНФОРМАЦЇ̈}

\section{О.В. Ефімов, Т.В. Потаніна}

Розглянуто застосування стандартного статистичного підходу і апарату інтервального аналізу до оцінки параметрів залежності потужності енергоблоку АЕС від температури пари на виході з першого ступеня сепаратора-пароперегрівника в умовах невизначеності інформації: наявності «шуму» у вимірах, невідомих ймовірнісних характеристиках похибок та достатньо малій вибірці спостережень. Досліджується вплив зменшення похибки визначення потужності енергоблоку на вибір методу обробки результатів експерименту. Розглядається ситуація обмеженості похибки вимірювань без достовірної інформації про ііі розподіл. Показана коректність застосування чисельних методів інтервального аналізу для обробки експериментальних даних в умовах невизначеності та зменшення максимального значення сумарної похибки. При стандартній 5\% відносній похибці результатів вимірювань застосовано апроксимацію даних методом мінімізації Левенберга-Марквардта. 